Haapanen, L., L. Kääntä \& L. Lehti (toim.) 2018. Diskurssintutkimuksen menetelmistä. On the methods in discourse studies. AFinLA-e. Soveltavan kielitieteen tutkimuksia 2018/n:o 11. 71-92.

\author{
Leena Kuure, Maritta Riekki \& Riikka Tumelius \\ University of Oulu
}

\title{
Nexus analysis in the study of the changing field of language learning, language pedagogy and language teacher education
}

\begin{abstract}
Researchers in a variety of fields have started to use nexus analysis in their studies as it has proven to be suited for examining phenomena of complex and changing nature. Nexus analysis is based on a mediated view of social action and interaction emerging from the interplay of three aspects: interaction orders between the people participating, their historical bodies encompassing their experiences and accustomed practices, and discourses in place reaching across multiple timescales and spaces. In discourse studies this entails a switch of focus from language to socio-semiotic meaning making as a whole. Nexus analysis proceeds by engaging, navigating and changing the nexus of practice under study. The tradition of nexus analysis is still young and seeking its form, which means that researchers apply the approach in different ways. This article presents a literature review of the use of nexus-analytic and/or mediated discourse perspectives in the examination of foreign language learning, language pedagogy and language teacher education. It sheds light on how the theoretical-methodological framework has been interpreted in these fields and how such research has been conducted in practice.
\end{abstract}

Keywords: nexus analysis, language learning, language pedagogy, language teacher education, change

Asiasanat: neksusanalyysi, kieltenoppiminen, kielipedagogiikka, kieltenopettajakoulutus, muutos 


\section{Introduction}

This article presents a literature review of the use of nexus-analytic and/or mediated discourse perspectives in the study of foreign language learning, language pedagogy and language teacher education. The rationale that researchers usually give for the use of nexus analysis in their studies is the complexity and change of phenomena under scrutiny. Nexus analysis is said to provide a research strategy that is suited to the examination of complex, evolving phenomena in situ, at the same time reaching into the past and projecting the future through anticipatory discourses (de Saint-Georges 2005, 2012). Nexus-analytic research may draw on multiple types of materials and methodologies but also engage with social actors related to the focus of study in various ways. In order to understand how nexus analysis has been applied in the study of such phenomena in educational contexts so far, we have decided to conduct a review of emerging research in the field.

Considering what kinds of changes are currently at work, the increasing pace of digitalisation poses an essential challenge bringing along new developments in communicative practices and the organisation of learning and work (e.g. Ferrari 2013). At the same time, conceptualisations of language use and language learning are broadening to encompass not only cognition but also interaction and participation, learning how to do things with language (Van Lier 2000; Dufva et al. 2014). For example, more emphasis is put on phenomenon-based learning approaches, which put weight on activities and languages in their context rather than language per se. These changing emphases are promoted in educational policies and are reflected in the curricula in relation to transversal competences, among other things. The changing focus of language pedagogy is further transforming the expectations set for teaching professionals (Dufva et al. 2014). Capturing the complex networks of aspects under change also requires new approaches in research as language learning is seen to take place in a range of sites and networks, distributed across time and space, not just in the classroom.

Nexus analysis is a research strategy that has been gaining increasing interest in the study of complex phenomena. It is a multidisciplinary approach that encompasses a mediated discourse perspective on social action. It is a recent research field, which has its roots in linguistic anthropology, interactional sociolinguistics and critical discourse studies among other areas (Scollon \& Scollon 2004; Al Zidjaly 2012; Scollon \& de Saint-Georges 2011). As Scollon and de SaintGeorges (2011) summarise the relationship between mediated discourse and nexus analysis, nexus analysis is the historical, ethnographic and methodological arm of mediated discourse analysis. The focus is on a social actor taking an action through some mediational means be it language or any other cultural tool (Wertsch 1991; Scollon 1998, 2001a, 2001b; Scollon \& Scollon 2004). As Figure 1 illustrates, social 
action takes place at the intersection of three aspects that are at work simultaneously, in interrelated configurations (Scollon \& Scollon 2004).

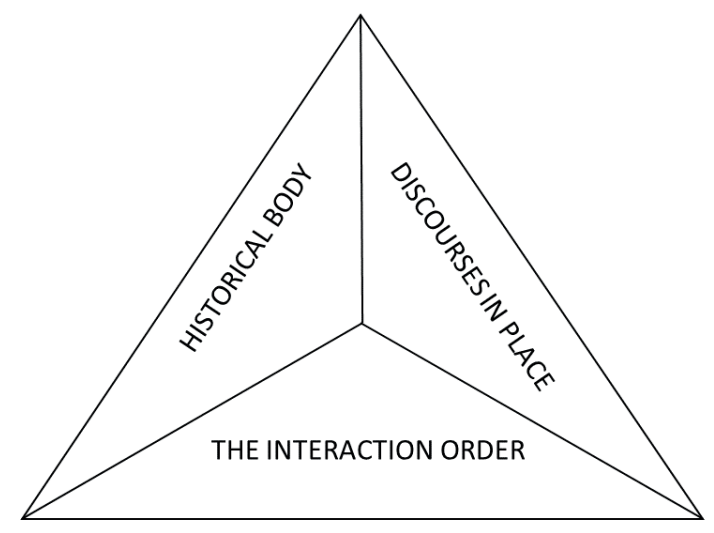

FIGURE 1. The interrelated aspects of social action. (Adapted from Scollon \& Scollon 2004.)

Social action emerges from the interplay of interaction orders (Goffman 1983) between the people participating, their historical bodies (Nishida 1958) encompassing their experiences and accustomed practices, and discourses in place which are approached by engaging, navigating and changing the nexus of practice (Scollon \& Scollon 2004). Social practice and discursive practice are mutually constitutive (Scollon 2001).

Scollon and Scollon (2004: 4-5) assume Gee's (1992, 1999) distinction between two levels of discourse. As they point out, discourse may refer broadly to "the ways in which people engage each other in communication" (ibid. 4). However, there is a higher level of meaning referring to Discourse with a capital D (Gee 1992, 1999), which encompasses different multimodal semiotic systems of social practices that people enact as members of different discourse communities, e.g., being parents, teachers, or politicians. Scollon and Scollon (2004: 5) also use the term social semiotics for broader discourses aligning with other scholars (e.g. Blommaert 2005). Thus, discourse-analytic research in nexus analysis entails a broader look at social action, not just situational text and talk. Discourses may operate in rhizomatic ways, i.e., through more or less overt complex linkages, as Pietikäinen (2015) suggests using Deleuze and Guattari's (1982) term in the context of changing language in the multilingual space of the Sámi people. Hult $(2007,2010)$ has also examined wider societal scales of language policy discourses (see also Hult \& Pietikäinen 2014). In other words, a mediated discourse perspective entails the interconnectedness of wider-scale policy making and language-related discourses at national or 
international levels with concrete actions and practices in situ (Hult 2015; see also Källkvist 2013).

Our own rationale to conduct nexus-analytic research has been to examine complexity and change in our field of interest. Our view of language learning relies broadly speaking on a sociocultural and ecological basis (see Vygotsky 1978; Van Lier 2000, 2004, 2010; Kramsch \& Whiteside 2007). The former term refers to "historical, cultural and social artefacts and activities providing tools and resources to mediate learning and action" (Van Lier 2004: 80). Activity in a meaningful environment creates affordances, relationships of possibility for learning (Van Lier 2000, 2004). As Van Lier (2010: 5) characterises the notion of ecology (originally coined by Gibson 1979), all the elements within an ecosystem (such as a classroom) are interrelated. Van Lier (2010) further points out that research may isolate "pieces of the complex puzzle" to study them in detail and thus obscure the bigger picture (ibid.5). This is another reason to develop a research approach to capture at the same time the detailed configurations of social action and their wider dimensions. This entails capturing both types of discourse ( $d$ and $D$ ) by using the nexus-analytic perspective.

Nexus analysis, used to tackle the complex issues at hand, has helped us to identify some challenges in redesigning language pedagogies in the modern world: 1) making sense of languages and language learning in people's everyday life as multimodal and networked practice, 2) problematising the views of language learning, 3) supporting language students in assuming new conceptions of their future profession as language teachers, 4) understanding the complexity of aspects contributing to change in language pedagogy, and 5) developing research approaches to study complexity. These challenges are intricately interconnected. With a review of nexus-analytic research into language learning, language pedagogy and language teacher education, we wish to shed light on how nexus analysis is currently being applied in these fields.

The following section outlines mediated discourse analysis and nexus analysis as research approaches and strategies of inquiry. Next, the principles and procedures of the literature review are explained and the survey of research is illustrated. Finally, the findings will be synthesised and discussed.

\section{Mediated discourse analysis and nexus analysis}

Norris and Jones (2005) argue that for a number of years, several scholars have been trying to develop ways to consider questions about the actions people take with various discourses or other cultural tools and about the possible social consequences these actions may have. These efforts have contributed to the emergence of mediated discourse analysis (MDA), and, later, nexus analysis (NA). Researchers sometimes use these terms interchangeably (see Scollon \& Scollon 
2007: 615). Sometimes a distinction is made depending on whether attention is paid to the nature of mediated discourse itself or its broader, even socio-political dimensions that are approached through a particular research strategy, i.e., nexus analysis as the methodological arm of mediated discourse analysis (Scollon \& de Saint-Georges 2011). In this paper, both terms are used, on the one hand, due to the use of terminology in the studies cited, and on the other hand, bringing forth the distinction referred to above.

In historical perspective, mediated discourse analysis as a term became established at the end of the $90 \mathrm{~s}$, although its roots stretch further back in the traditions of linguistic anthropology, interactional linguistics and critical discourse analysis to name a few (Scollon 1998, 2001a, 2001b). An important phase was the early 1980s, when Ron and Suzy Scollon began examining the semiotic cycles of people, objects and discourses and the use of the Internet for educational purposes in Alaska (Scollon \& de Saint-Georges 2011).

The focus of analysis was on mediated social action which was seen as an intersection of: 1) the 'interaction order' or mutual relationships and power positions between the participants taking the action, 2) their 'historical bodies' or accumulated experience, memories and accustomed practices and 3) 'discourses in place' (Scollon 2001a, 2001 b; Scollon \& Scollon 2003, 2004). The approach draws on a view of human action and interaction mediated by diverse (mediational) means or cultural tools along the lines of Vygotskian (1981) and Bakhtinian (1981) thought (see Jones 2013). Here, the idea of mediated action and mediational means draws on the same background as cultural-historical activity theory (see Engeström 1987; Wertsch 1991).

The concept of interaction order dates back to Goffman (1981), while the concept of the historical body related to Bourdieu's (1977) habitus ties in with Nishida's (1958) theorisation of historical life acting-reflecting. Key terms include action, agency, communities, culture and time (Norris \& Jones 2005: xi; Scollon \& de Saint-Georges 2011). In mediated discourse theory, the perspective switches from discourse alone to social action (Scollon 2001 b; see also Norris 2016). The relationship between discourse and action is problematised by posing the following questions: 1) What is the action taken here? 2) What is the role of discourse in this action? (Jones \& Norris 2005: 9). Scollon and Scollon (2004: 14) see material places as complex aggregates (nexus) of discourses that circulate through them; some at a slower pace (e.g. the aging of the built environment) and some more rapidly (e.g. conversational topics among friends). Some discourses are more relevant or foregrounded than others from the point of view of the social action in question. Scollon and Scollon's (2004: 4-7) view of discourse entails Gee's (e.g. 1992, 1999) idea of language-in-use ("little $\mathrm{d}$ " discourses) being embedded into different multimodal semiotic systems of social practices ("big D" discourses) that people enact as members of different discourse communities (see also Gee 2015). They further refer to Blommaert's (2005: 
3) characterisation of discourse as "all forms of meaningful semiotic human activity seen in connection with social, cultural and historical patterns and developments of use".

Jones and Norris (2005: 9) suggest that the relationship between discourse and action is dynamic and contingent, located at a nexus of social practices, social identities and goals. In other words, discourse is seen as "cycling" through actions: verbal and textual tools entering practices, material objects, and the environments in which we interact. Those practices, tools and environments then transform or reproduce discourses. Scollon and Scollon (2004) argue that the embedded practices in various discourse systems differentiate the systems from each other, and the participants are socialised in diverse forms and to varying extents in these discourse systems. A discourse analysis should always include a broad range of mediational means such as objects, gestures, nonverbal sounds and built environments (Scollon 1998, 2001b). In Scollon and Scollon (2003), the authors discuss geosemiotics which brings visual and place semiotics in particular into the foreground.

An important overall stance in nexus analysis is an ethnographic perspective. However, Scollon and Scollon (2007: 619) distance themselves from the focus of traditional ethnography and the ethnography of communication. Instead of examining groups of people, nexus analysis looks at mediated action as described above as a starting point. Nexus analysis also offers possibilities to combine various research strategies in order to study participants, context, discourses and objects as well as to facilitate action and change reciprocally (Dooly 2017). Researchers conducting nexus analysis are not viewing activities from a distance as objective observers. Instead, they enter the zone of identification, becoming accepted legitimate participants in the nexus of practice (Pan 2014). Thus, doing nexus analysis may become a project to promote social change (Jones \& Norris 2005: 10). Change also takes place in minute moments as the interaction order between participants is in flux (Scollon \& Scollon 2004). Change can be seen even in the way people engage in anticipatory discourses, i.e., how individuals, texts, or utterances project representations of future events, states, or relations (de Saint-Georges 2012).

\section{Research approach}

Journals tend to publish literature reviews in specific domains of research approaching a topic in different ways. Rogers and Schaenen (2014), for example, shed light on CDA studies in literacy education in a broad range of journals. Kleinsasser's (2013) review makes a synthesis of research published in one particular journal on the topics of language teachers, language teacher education, teaching and learning. Hartwick (2018) again outlines historical developments of language learning research in her review. However, the literature review in this article focused on nexus-analytic 
and mediated-discourse perspectives in the study of language learning, language pedagogy and language teacher education. Research on multimodal practices and literacies as well as learning environments was checked for suitable sources as well.

As described in the previous section, MDA and NA have been used in various fields of research exploring social action from the 1980s onwards in the wider field of education. For example, there is research utilising nexus analysis to map the trajectories of language policies and planning, analysing their presence in the practices of language education and interaction in the classroom (e.g. Hult 2007, 2010; Compton 2013), or research looking into literacy practices or teacher education without a connection to foreign language learning (e.g. Räisänen 2015). However, within our three focus areas, there is scarcely any nexus-analytic research available so far. Nevertheless, it is an emerging field of research with an evolving terminology drawing on varied methodological and theoretical frameworks. Thus, there is no established set of keywords to use for an information search. In our search, we tried to be as systematic as possible. Some creative strategies were employed, however, for finding relevant contributions in the focus area of the analysis.

We used multiple databases and search terms to cover a range of studies as widely as possible. Electronic searches were conducted in databases of ProQuest, Ebsco, Scopus and the Web of Science as well as Google Scholar. The queries were based on the following search terms: nexus analysis, mediated discourse analysis, language learning, language teaching, language pedagogy, language education and language teacher education. Additionally, we searched for studies citing key authors (Scollon, Jones, Norris, de Saint-Georges) in combination with search terms for language learning and teaching. Peer reviewed articles were the first target, but details were gathered also from other types of publications such as book chapters in edited volumes, methodological handbooks as well as doctoral theses (if they were publicly available). The search thus produced a collection of 33 publications out of which five were doctoral theses.

Some sources were examined even if they seemed on the surface to be only marginally relevant from the perspective of foreign language learning. The multimodal nature of language learning as literacy appropriation was prevalent in these studies. Furthermore, some studies on language policy-making and multiliteracies were relevant for similar reasons but also because mediated discourse analysis and nexus analysis entail mapping traces of broader socio-political nature in particular sites of engagement. These were included in Table 1 (in the next section) if the link to foreign language learning, language pedagogy or language teacher education was seen to be strong enough.

Within the search results, we also found studies which used MDA as a backdrop for conceptualising language learning in particular circumstances. However, these studies did not explicitly utilise the concepts of MDA or NA in the analysis and therefore fell outside this review. 
In the analysis of the publications, a form was created to highlight the aspects important for this article: the source of the study, the research focus and setting, the way nexus analysis or mediated discourse analysis had been applied and the main results. A synthesis of the results is presented in the following section.

\section{Findings}

The search produced a body of research that is relevant for the study of foreign language learning and teaching as well as language teacher education. Although the special issue of the journal at hand explores recent trends in discourse studies in Finland today, research beyond Finland was also included. As the tradition of nexus-analytic research is still young and seeking its form, researchers still have the opportunity to follow quite closely how other researchers are applying nexus analysis and have a strong grip on the development of the field. In the areas reviewed, studies situated in the Finnish context comprised approximately one third of all the nexus-analytic research. There was considerable variation in how mediated discourse analysis and nexus analysis had been applied. Table 1 summarises the studies from the point of view of their focus, research context, and the participants involved.

In the studies, the general rationale presented for the methodological choice was the capacity of the mediated discourse and nexus analytical approach to capture the complexity of the phenomenon under scrutiny as well as the aspect of change. Sometimes, the authors highlighted a methodological interest, while in other cases they only briefly mentioned the methodology discussing the issues without particular attention to the nexus-analytic concepts. The topics of the studies included areas such as the appropriation of literacies, advancing new language pedagogies, as well as language teacher education as a site for generating change in the field. In these studies, language learning was seen as emerging from the learners' engagement in activities in meaningful environments (Van Lier 2004; Dufva et al. 2014). In the following, the findings will be discussed in more detail. 


\begin{tabular}{|c|c|c|}
\hline $\begin{array}{l}\text { NEW PERSPECTIVES ON } \\
\text { LANGUAGE LEARNING } \\
\text { AND LITERACIES }\end{array}$ & CONTEXT & PARTICIPANTS \\
\hline $\begin{array}{l}\text { Levine (2015) } \\
\text { Källkvist (2013) }\end{array}$ & $\begin{array}{l}\text { higher education; USA } \\
\text { higher education; Sweden }\end{array}$ & $\begin{array}{l}\text { university students abroad } \\
\text { university students, their } \\
\text { teacher }\end{array}$ \\
\hline $\begin{array}{l}\text { Rish (2015); Rish \& Caton } \\
\text { (2011) }\end{array}$ & high school; USA & high school students \\
\hline $\begin{array}{l}\text { Rosén \& Bagga-Gupta } \\
\text { (2015) }\end{array}$ & $\begin{array}{l}\text { tailored education for adult } \\
\text { immigrants; Sweden }\end{array}$ & adult immigrants \\
\hline $\begin{array}{l}\text { Partanen (2013); Strömmer } \\
\text { (2016a), Strömmer } \\
\text { (2016b), Strömmer (2017a): } \\
\text { Strömmer (2017b); }\end{array}$ & $\begin{array}{l}\text { cleaning work; } \\
\text { Finland }\end{array}$ & immigrants \\
\hline Tapio (2013); Tapio (2014) & $\begin{array}{l}\text { deaf education, } \\
\text { international online } \\
\text { project, everyday } \\
\text { situations; Finland }\end{array}$ & $\begin{array}{l}\text { Finnish Sign-Language signers } \\
\text { at a primary school }\end{array}$ \\
\hline Virtanen (2017) & nursing work; Finland & immigrants \\
\hline $\begin{array}{l}\text { Wohlwend (2009); } \\
\text { Wohlwend \& Handsfield } \\
\text { (2012) }\end{array}$ & kindergarten; USA & 5-6-year-olds, a teacher \\
\hline $\begin{array}{l}\text { Kuure (2011); Kuure \& } \\
\text { McCambridge (2007) }\end{array}$ & beyond school; Finland & adolescents \\
\hline $\begin{array}{l}\text { REDESIGN OF LANGUAGE } \\
\text { PEDAGOGY }\end{array}$ & CONTEXT & PARTICIPANTS \\
\hline Dressler (2015) & $\begin{array}{l}\text { bilingual education, } \\
\text { elementary school; Canada }\end{array}$ & school pupils \\
\hline Koivisto (2013) & $\begin{array}{l}\text { lower-secondary school; } \\
\text { Finland }\end{array}$ & 13-year-olds, a teacher \\
\hline $\begin{array}{l}\text { Koivistoinen (2008) } \\
\text { Koivistoinen (2014); } \\
\text { Koivistoinen (2016a); } \\
\text { Koivistoinen (2016b) }\end{array}$ & $\begin{array}{l}\text { primary school, } \\
\text { international online } \\
\text { project; home; Finland }\end{array}$ & 10-12-year-olds, parents \\
\hline $\begin{array}{l}\text { Pietikäinen \& Pitkänen- } \\
\text { Huhta (2013) }\end{array}$ & $\begin{array}{l}\text { primary school, Sámi } \\
\text { language classroom; } \\
\text { Finnish Sámiland }\end{array}$ & $\begin{array}{l}\text { multilingual indigenous Sámi } \\
\text { children }\end{array}$ \\
\hline Levine (2012) & $\begin{array}{l}\text { higher education; } \\
\text { intermediate-level German } \\
\text { language course; USA }\end{array}$ & college students \\
\hline
\end{tabular}




\begin{tabular}{|c|c|c|}
\hline $\begin{array}{l}\text { LANGUAGE TEACHER } \\
\text { EDUCATION OR } \\
\text { PROFESSIONAL GROWTH }\end{array}$ & CONTEXT & PARTICIPANTS \\
\hline $\begin{array}{l}\text { Dooly (2017); Dooly \& } \\
\text { Sadler (2013) }\end{array}$ & $\begin{array}{l}\text { higher education; } \\
\text { Catalonia and USA }\end{array}$ & teacher students \\
\hline $\begin{array}{l}\text { Ensor, Kleban \& Rodrigues } \\
\text { (2017) }\end{array}$ & $\begin{array}{l}\text { a telecollaborative } \\
\text { research project, a } \\
\text { learning network; France, } \\
\text { UK, Poland }\end{array}$ & $\begin{array}{l}\text { in-service and pre-service } \\
\text { foreign language teachers }\end{array}$ \\
\hline $\begin{array}{l}\text { Koivistoinen, Kuure \& Tapio } \\
\text { (2016); Kuure, Keisanen \& } \\
\text { Riekki (2013); Kuure, Molin- } \\
\text { Juustila, Keisanen, Riekki, } \\
\text { livari \& Kinnula (2016) } \\
\end{array}$ & higher education; Finland & language teacher students \\
\hline $\begin{array}{l}\text { Palviainen \& Mård- } \\
\text { Miettinen (2015) }\end{array}$ & $\begin{array}{l}\text { bilingual pre-school } \\
\text { education; professional } \\
\text { growth; Finland }\end{array}$ & a bilingual pre-school teacher \\
\hline Riekki (2016) & $\begin{array}{l}\text { schools, university, } \\
\text { administration; Finland }\end{array}$ & $\begin{array}{l}\text { pupils, language students and } \\
\text { teachers, education authorities }\end{array}$ \\
\hline
\end{tabular}

TABLE 1. Themes, contexts and participants in the studies reviewed.

\subsection{New perspectives on literacy and language learning}

There are studies drawing on mediated discourse and nexus analysis that provide interesting perspectives for research in foreign language pedagogy and language teacher education even if their interest falls in other areas. Wohlwend (2009), for example, has written abundantly about the relationship between literacy and play in early childhood, combining ethnographic, activity-theoretical and mediated discourse perspectives among others. Her microanalysis in early childhood classrooms sheds light on how social practices, positioning and spaces allowed children to both include and exclude peers. Here, the participants (five to six years old) were primarily monolingual English speakers while some children had a more versatile language background. The analysis pointed out how the mediated discourse perspective may "provide analytic tools for investigating non-verbal actions as constitutive elements in social practices that are key to learning and development in school communities" (ibid. 240).

Wohlwend and Handsfield (2012) enrich mediated discourse analysis with rhizoanalysis (Deleuze \& Guattari 1987) in their study of a "techno-toddler". The former was employed in selecting and analysing a parent-produced YouTube video describing a two-year-old's technology-related literacy practices, e.g., switching on the computer, turning on YouTube, browsing videos and switching off. Rhizoanalysis traced not only linked actions and clustered practices but also their divergence, all 
in constant flux and emergence. The combination of the two approaches produced a more versatile picture of how the toddler was discursively produced as vulnerable or innocent (as defined by Cannella 1997) but at the same time as a technologysavvy digital native (Prensky 2001). Rhizoanalysis has also been used in the study of language identities and multilingual dynamics in areas where Sámi languages are endangered (Pietikäinen 2012, 2015).

Rish (2015), based on Rish and Caton (2011), conducted a study of three high school students singled out from an elective English class, exploring how authors, movie directors and video game designers create fictional worlds in the genres of science fiction and fantasy. The central activity for the students was to create a fictional world through collaborative writing, digital cartography, image design and video game design. The analysis focused on collaborative writing events while creating a wiki. The study revealed how the authorship was distributed between the group members and what kinds of resources mediated their writing. Furthermore, it was shown how discourses from diverse time-spaces became salient in the writing event. What becomes registered in the wiki is an outcome of many interactions and experiences (Rish 2015). Again, this study did not focus on (foreign) language learning as such. Nevertheless, considering the socio-cultural basis in the foreign language curricula, the course could well provide a context for foreign language teaching as well. From the perspective of language pedagogy, the study also reminds us of the importance of looking beyond the student's written or spoken product to trace its emergence as an outcome of a range of participants with their histories and situated discourses.

Tapio (2014) points out that the multimodal view (Norris 2004; Goodwin 2000; Van Leeuwen 2005) is integrated in mediated discourse analysis. The study further discusses the main findings from an earlier doctoral thesis (Tapio 2013) that focused on the networked and multimodal practices of Finnish Sign Language (FinSL) signers in educational settings and everyday situations. The study showed how the participants employed a wide variety of resources in language learning. These resources were, however, not recognised or used actively in formal education.

Nexus analysis has been applied in the study of school environments as in Dressler's (2015) investigation of promoting bilingualism during a period of five months. During the engaging phase of the research, the linguistic landscape was mapped through photographs taken by the researcher. The study then proceeded to navigating the nexus of practice in more detail: photographs were analysed and discussed with the teachers with special reference to what the origins of and reasons for signage were. Change was seen to arise from the interactions with the teachers while discussing what kinds of consequences signage practices might have for the linguistic situation at the school. Levine's (2015) study on code-choice practices in the case of US students living in Germany links NA to complexity theory and dynamic systems theory. Here a combination of discourse and narrative analysis of 
interviews, surveys and Facebook postings was used to delve into the identities and intercultural positioning of the students. Källkvist (2013) focused on how different types of tasks (translation and composition) in a foreign language class for university students facilitated interaction.

Strömmer (2016a, 2016b, 2017b) has examined immigrants'language learning in cleaning work in Finland. Strömmer (2016a: 715) focused on the interaction order in particular showing how cleaners employed by outsourced services were isolated both from the work community of the cleaning company and that of the client's. This involved limited access to opportunities for language learning from Finnish workers. Strömmer (2016b) showed how diverse types of material scaffolding provided by colleagues facilitated understanding and performing the work (e.g. use of body, gaze, space and material artefacts in communication). Strömmer (2017b) studied the ways in which two research participants positioned themselves and how they were positioned by others as language learners when narrating their trajectories of workrelated language learning during ethnographic research interviews. The positioning was examined through the small stories approach developed by Bamberg and Georgakopoulou (2008).

According to Strömmer (2017b: 137), another important aspect of language learning in the workplace was the degree of the participants' investment (Darvin \& Norton 2015) or commitment to developing their language skills to achieve their aspirations. As the study shows, the investment becomes understandably meaningful when occupational development and language learning can be purposefully combined. However, migrants tend to be positioned as potential members of the workforce rather than full members of the work community. As their expertise is ignored, their investment in language learning may not lead to development in their career paths (Strömmer 2017b: 154-155). These studies together with Partanen (2013) have been further elaborated in the framework of nexus analysis (Strömmer 2017a).

Virtanen's (2017) study on international nursing students' documentation skills in Finnish in a hospital environment during practical training shows the heteroglossic nature of workplace literacies. The nurses' documenting brought into dialogue the mentor's and the student's historical bodies, the former related to workplace literacies and the latter to second language learner histories. Rosén and Bagga-Gupta (2015), too, have studied language learning among immigrants but in the Swedish context of formal education. The study shed light on how language policy is made and re-created in everyday language practices in the classrooms, thus, showing similarly as the studies above how nexus analysis combines minute perspectives of social action with wider societal discourses. 


\subsection{Redesign of language pedagogy}

In many of the studies reviewed, the research interest was directed towards the need to rethink current practices of language teaching in the modern world. These studies approached the topic from the point of view of teachers reflecting on their pedagogic choices in transformation. Koivisto (2013), for example, examined his own English class of thirteen-year-old seventh-graders when mobile devices were taken into use. He used nexus analysis to trace the changes in social actions and interactions over seven months. The study showed the tensions and challenges related to the teacher's attempts to support the emergence of new kinds of interaction orders and agency growth while the pupils resisted taking an active role due to their historical bodies as language learners in a teacher-led classroom.

Koivistoinen's (2016a) article-based doctoral thesis employing nexus analysis binds together four studies that were part of a wider research context involving an international online English learning project for 10-12-year-olds. The thesis approached change in understandings concerning language teaching. Out of the studies, the first shed light on the children's views of participating in the project (Koivistoinen 2008). Koivistoinen $(2014,2016 b)$ focused on the perspectives of two pupils in particular. Visits to the pupils' homes shed light on the resources of the home environment for language learning and also on the roles of the parents as important language educators drawing on their own historical bodies as language learners. The final study (Koivistoinen et al. 2016) examined the topic from the perspective of language teacher education (see the section below).

Levine (2012) discusses ways of employing NA in the pedagogical context of foreign language teaching and learning with reference to complexity theory and dynamic systems theory (Larsen-Freeman \& Cameron 2008; Larsen-Freeman 2010). The specific context for this study was a college-level intermediate German class where the examination of literary texts provided a starting point for the teaching of complex representations of history. Here, NA was utilised as a way to structure and organise pedagogical decisions regarding the classroom study of texts (Levine 2012: 172). The social action under scrutiny was delineated as "the social practice and discourses of studying an L2 literary text in its multiple historical contexts" (ibid. 173). Multiple histories of different timescales were generated around wartime texts changing them from language-class objects of analysis to tools for building students' awareness concerning historical and political developments (Levine 2012: 173, 187).

\subsection{Language teacher education}

A considerable number of studies found in the search focused on language teacher education dealing with beliefs, identities and practices in flux. Nexus analysis is seen 
as a suitable strategy for exploring the interplay of complex networks of aspects in developing language teaching. Drawing on their findings in a telecollaboration context, Ensor et al. (2017) suggest that teacher identity results from a complex interplay of institutional, professional and informal discourses which may be both obstacles and bridges to pedagogical transformation. Kuure et al. (2016) combined cultural-historical activity theory with nexus analysis. They showed how the language students' past experiences of language learning in formal contexts were tightly intervowen with their pedagogical choices and visions. As these experiences were primarily connected with traditional practices and sites of language learning, envisioning new kinds of scenarios for language learning and teaching in more distributed (hybrid) environments seemed to be difficult. Kuure et al. (2013) approached the same pedagogic setting from the point of view of the guidance given to the students. Students were led through various mediational means, e.g., spoken or written instructions, but also the overall pedagogic design of the course reflected in the structuring of the online course environment and the activities taken during the process (see Pietikäinen et al. 2011 for a treatment of frozen actions in the linguistic landscape).

An important aspect of language teacher education is learning professional practice. This involves exploring current beliefs and understandings as well as visions of future language pedagogy. Koivistoinen et al. (2016) examine university students of English and their teachers appropriating an ecological perspective into language learning and teaching during a university course. They apply Scollon's (2008) idea of discourse itineraries based on the concept of resemiotisation (ledema 2001, 2003). This study also draws on multiple types of data from different spatial and temporal orientations. Language students (teachers to be), together with their teacher and researchers were drawing on different multimodal resources to make sense of how to design a socioculturally and ecologically informed online language project for children from different countries. Riekki (2016) shares this research interest tackling the challenges of change through the use of cultural probes, e.g., various arts and crafts materials for provoking inspirational responses to be used in design (see Gaver et al. 1999) as mediational means for rethinking language pedagogy and futures for language learning. Dooly and Sadler (2013: 197) focus on "practices designed to promote novice teachers' process of professionalization through technologyenhanced education courses". The use of mediated discourse analysis explores how related chains of mediated actions and interactional events across contexts are related to social practices within a wider nexus of practice, as Dooly (2017: 206) suggests.

Riekki (2016) in her doctoral thesis approaches the problematics of change in five cases across four years applying a nexus-analytic research strategy. The participants included school pupils, language students and teachers as well as foreign language education authorities. The study shows the complex connections 
of aspects related to change in the field. In the same vein, Palviainen and MårdMiettinen (2015) conduct a nexus analysis of a preschool teacher in Finland working bilingually with a class of monolingual children for the first time. The analysis of an interview shed light on how the new language practices demanded renegotiation in relation to previously held personal and professional beliefs. Diverse concepts, places and people circulated in her reflections and these were also connected to larger societal discourses (Palviainen \& Mård-Miettinen 2015).

\section{$5 \quad$ Discussion and conclusion}

The aim of this article was to present a literature review of the use of nexus-analytic and mediated-discourse perspectives in the study of foreign language learning, language pedagogy and language teacher education. Figure 2 illustrates the thematics that were brought to light in our review.

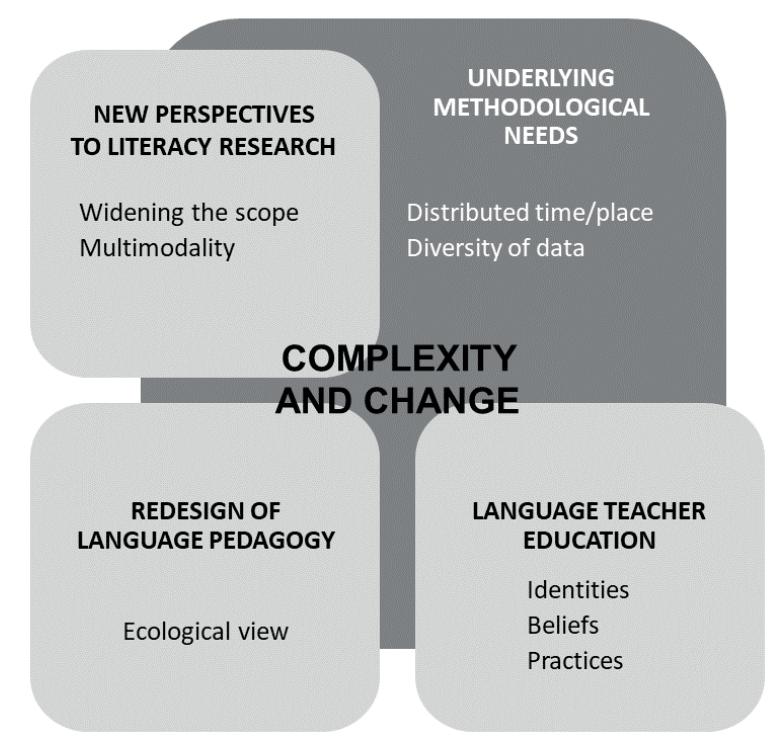

FIGURE 2. Nexus analysis in the study of foreign language learning, language pedagogy and language teacher education.

The studies related to the redesign of language pedagogy focused on new directions in a variety of ways. In many cases, a switch from reflective practitioner (Schön 1987) to researcher was visible as the teachers studied topics that arose from their own work. Nexus analysis led them to view language learning not only in the situational context but also as a form of sense making with respect to the participants' earlier experiences, accustomed practices and multiple discourses present in situ echoing 
old practices and anticipating new ones. A look was taken at learners' lives beyond the school and this involved looking at how learners engaged in meaning making with other participants who contributed to their growth and language learning, i.e., the family. Nexus analysis was here seen as a change-making activity which helped the parents to elaborate their understandings of language learning together with the teacher-researcher.

In relation to language teacher education, challenges were seen in future language teachers' professional growth to meet the needs of a world that is technology-rich and linguistically superdiverse (Blommaert \& Backus 2013). Nexus analysis shed light on the complexity of aspects guiding the ways in which the professional field of language pedagogy was developing. In connection with projects of different kinds, the participants explored new identities as language teachers. Teacher educators considered how to contribute to change in pedagogic traditions. Voices from broader societal actors were also discernible.

Generally, the authors of the papers examined in the review considered the challenges of studying complex phenomena under constant change to provide the rationale for their methodological choice. Their approaches also relied largely on a sociocultural understanding of language learning, which requires a look at longterm trajectories rather than achievements in one-time test situations. Language learning was viewed as taking place in everyday life, in formal situations, but also in free time activities. Therefore, researchers also need strategies for understanding how these sites together provide an environment for appropriating language practices. This involves dealing with multimodal data in different formats, e.g., audio, video, artefacts and fieldnotes, but also from different spatial orientations and times with the aim of seeing the interconnectedness of the phenomena under scrutiny (Dooly 2017, referring to Dooly \& Sadler 2013).

As for the ways in which nexus analysis had been applied in the studies, some main approaches could be discerned. Some researchers used the concepts of interaction order, historical body and discourses in place as heuristic tools in the analysis - in some cases explicitly using the terms in the analysis and in some cases implicitly explaining the framework at the beginning and conducting the analysis in their spirit but without referring to the terminology. The second way to apply nexus analysis was to see it as an overall research strategy (engaging, navigating and changing). In this case, different types of data and methodologies were used at times zooming in to shed light on a particular event or aspect of interest, and zooming out again, i.e., to see "how discourses from (inter)personal scales and societal scales intersect" (Hult 2015: 228). In some cases, the nexus-analytic research strategy had been followed from the outset of the research. In others, the study had started as an ethnographic or qualitative study and later transformed or was re-interpreted in the framework of nexus analysis. 
The review of research using mediated discourse and nexus analytic approaches in the fields of language learning, language pedagogy and language teacher education was necessarily limited as the tradition is still young and the research available is scarce. There is still considerable fluctuation in how the theoretical-methodological framework is interpreted and how such research is conducted in practice. Looking at the abundance of conference papers visible in programmes of international conferences on language studies it seems that in future years the research gathered for this article will be complemented with an outburst of new research drawing on mediated discourse and nexus-analytic perspectives.

\section{References}

Al Zidjaly, N. 2012. Scollon, Ron. The encyclopedia of applied linguistics. London: Blackwell. https://doi.org/10.1002/9781405198431.wbeal1043.

Bakhtin, M. M. 1981. The dialogic imagination: four essays (ed. by M. Holquist, trans. C. Emerson \& M. Holquist). Austin, TX: University of Texas Press.

Bamberg, M. \& A. Georgakopoulou 2008. Small stories as a new perspective in narrative and identity analysis. Text and Talk, 28 (3), 377-396. https://doi.org/10.1515/ TEXT.2008.018.

Blommaert, J. 2005. Discourse - a critical introduction. Cambridge: Cambridge University Press.

Blommaert, J. \& A. Backus 2013. Superdiverse repertoires and the individual. In I. de SaintGeorges \& J. Weber (eds) Multilingualism and multimodality. Rotterdam: Sense Publishers, 11-32. https://doi.org/10.1007/978-94-6209-266-2.

Bourdieu, P. 1977. Outline of a theory of practice. Cambridge: Cambridge University Press.

Cannella, G. S. 1997. Deconstructing early childhood education: social justice and revolution. New York, NY: Peter Lang.

Compton, S. E. 2013. Implementing language policy for deaf students in a Texas school district. International Multilingual Research Journal, 7 (2), 138-154. https://doi.org/10. 1080/19313152.2012.665203.

Darvin, R. \& B. Norton 2015. Identity and a model of investment in applied linguistics. Annual Review of Applied Linguistics, 35, 36-56. https://doi.org/10.1017/S0267190514000191.

Deleuze, G. \& F. Guattari 1987. A thousand plateaus: capitalism and schizophrenia. (B. Massumi, Trans.). Minneapolis, MN: University of Minnesota Press.

De Saint-Georges, I. 2005. From anticipation to performance. Sites of engagement as process. In S. Norris \& R. H. Jones (eds) Discourse in action: introducing mediated discourse analysis. London: Routledge, 155-166.

De Saint-Georges, I. 2012. Anticipatory discourse. In C.A. Chapelle (ed.) The encyclopedia of applied linguistics. Oxford: Wiley. https://doi.org/10.1002/9781405198431.wbeal0032.

Dooly, M. 2017. A mediated discourse analysis (MDA) approach to multimodal data. In E. Moore \& M. Dooly (eds) Qualitative approaches to research on plurilingual education. Dublin: Research-publishing.net, 189-211. https://doi.org/10.14705/rpnet.2017. emmd2016.628.

Dooly, M. \& R. Sadler 2013. Filling in the gaps: linking theory and practice through telecollaboration in teacher education. ReCALL, 25 (1), 4-29. https://doi.org/10.1017/ S0958344012000237. 
Dressler, R. 2015. Signgeist: promoting bilingualism through the linguistic landscape of school signage. International Journal of Multilingualism, 12 (1), 128-145. https://doi.or $\mathrm{g} / 10.1080 / 14790718.2014 .912282$.

Dufva, H., M. Aro \& M. Suni 2014. Language learning as appropriation: how linguistic resources are recycled and regenerated. AFinLA-e: Soveltavan kielitieteen tutkimuksia, 6, 20-31. https://journal.fi/afinla/article/view/46278.

Engeström, Y. 1987. Learning by expanding: an activity-theoretical approach to developmental research. Helsinki: Orienta-Konsultit.

Ensor, S., M. Kleban \& C. Rodrigues 2017. Telecollaboration: foreign language teachers (re) defining their role. Alsic - Language Learning and Information and Communication Systems, 20 (2). https://doi.org/10.4000/alsic.3140.

Ferrari, A. 2013. DIGCOMP: A framework for developing and understanding digital competence in Europe. JRC Scientific and Policy Reports 26035. Publications Office of the European Union.

Gaver, W., A. Dunne \& E. Pacenti 1999. Design: cultural probes. Interactions, 6 (1), 21-29. https://doi.org/10.1145/291224.291235.

Gee, J. P. 1992. The social mind: language, ideology, and social practice. New York: Bergin \& Garvey.

Gee, J. P. 1999. An introduction to discourse analysis: theory and method. London: Routledge.

Gee, J. P. 2015. Discourse, small d, big D. In K. Tracy, C. llie \& T. Sandel (eds) The international encyclopedia of language and social interaction. Oxford: Wiley-Blackwell, 418-422. https://doi.org/10.1002/9781118611463.wbielsi016.

Gibson, J. 1979. The ecological approach to visual perception. Boston: Houghton Mifflin.

Goffman, E. 1981. Forms of talk. Pennsylvania: University of Pennsylvania Press.

Goffman, E. 1983. The interaction order: American Sociological Association, 1982 presidential address. American Sociological Review, 48 (1), 1-17. https://doi.org/10.2307/2095141.

Goodwin, C. 2000. Action and embodiment within situated human interaction. Journal of Pragmatics, 32 (10), 1489-1522. https://doi.org/10.1016/S0378-2166(99)00096-X.

Hartwick, P. 2018. Investigating research approaches: classroom-based interaction studies in physical and virtual contexts. ReCALL, 30 (2), 161-176. https://doi.org/10.1017/ S0958344017000386.

Hult, F. M. 2007. Multilingual language policy and English language teaching in Sweden. Unpublished doctoral thesis, University of Pennsylvania, USA. Dissertation available from ProQuest. https://repository.upenn.edu/dissertations/AAl3260918.

Hult, F. M. 2010. Analysis of language policy discourses across the scales of space and time. International Journal of the Sociology of Language, 2010 (202), 7-24. https://doi. org/10.1515/ijsl.2010.011.

Hult, F. M. 2015. Making policy connections across scales using nexus analysis. In F. M. Hult \& D. C. Johnson (eds) Research methods in language policy and planning: a practical guide. Malden, MA: Wiley-Blackwell, 217-231. https://doi. org/10.1002/9781118340349.ch19.

Hult, F. M. \& S. Pietikäinen 2014. Shaping discourses of multilingualism through a language ideological debate. The case of Swedish in Finland. Journal of Language and Politics, 13 (1), 1-20. https://doi.org/10.1075/jlp.13.1.01 hul.

ledema, R. 2001. Resemiotization. Semiotica, 137 (1-4), 23-39. https://doi.org/10.1515/ semi.2001.106.

ledema, R. 2003. Multimodality, resemiotization: extending the analysis of discourse as multi-semiotic practice. Visual Communication, 2 (1), 29-57. https://doi.org/10.1177/1 470357203002001751. 
Jones, R. H. 2013. Analysis of mediated interaction. In C. Chapelle (ed.) The encyclopedia of applied linguistics. Oxford: Blackwell, 86-91.

Jones, R. H. \& S. Norris 2005. Discourse as action/discourse in action. In S. Norris \& R. H. Jones (eds) Discourse in action. Introducing mediated discourse analysis. London: Routledge, 3-14.

Kleinsasser, R. C. 2013. Language teachers: research and studies in language(s) education, teaching, and learning in Teaching and Teacher Education, 1985-2012. Teaching and Teacher Education, 29, 86-96. https://doi.org/10.1016/j.tate.2012.08.011.

Koivisto, T. 2013. Historical bodies meet mobile devices in the English classroom. AFinLA-e: Soveltavan kielitieteen tutkimuksia, 5, 113-122. https://journal.fi/afinla/article/ view/8742.

Koivistoinen, H. 2008. Computer-mediated English language learning 'in a Beehive'. AFinLA Yearbook, 38 (66), 235-254. https://journal.fi/afinlavk/article/view/59992.

Koivistoinen, H. 2014. Crossing geographies of language learning - the case of 'a successful pupil', Classroom Discourse, 6 (1), 20-32. https://doi.org/10.1080/19463014.2014.893 895.

Koivistoinen, H. 2016a. Changing understandings of language learning and teaching: the perspectives of pupils, parents and future language teachers. Acta Universitatis Ouluensis. B Humaniora 147. University of Oulu. http://urn.fi/ urn:isbn:9789526214122.

Koivistoinen, H. 2016b. Negotiating understandings of language learning with Elli and her parents in their home. Apples - Journal of Applied Language Studies, 10 (2), 29-44. https://doi.org/10.17011/apples/urn.201610044265.

Koivistoinen, H., L. Kuure \& E. Tapio. 2016. Appropriating a new language learning approach: Processes of resemiotisation. Apples - Journal of Applied Language Studies, 10 (2), 105-117. http://dx.doi.org/10.17011/apples/urn.201612145091.

Kramsch, C. \& A. Whiteside 2007. Three fundamental concepts in second language acquisition. The Modern Language Journal, 91, Focus Issue, 907-922. https://doi. org/10.1111/j.1540-4781.2007.00677.x.

Kuure, L. 2011. Places for learning: technology-mediated language learning practices beyond the classroom. In P. Benson \& H. Reinders (eds) Beyond the language classroom. Basingstoke: Palgrave Macmillan, 35-46.

Kuure, L., T. Keisanen \& M. Riekki. 2013. Guiding towards genuine participation. In E. Christiansen, L. Kuure, A. Mørch \& B. Lindström (eds) Problem-based learning for the 21st century. New practices and learning environments. Aalborg: Aalborg University Press, 259-281.

Kuure, L., T. Molin-Juustila, T. Keisanen, M. Riekki, N, livari \& M. Kinnula 2016. Switching perspectives: from a language teacher to a designer of language learning with new technologies. Computer Assisted Language Learning, 29 (5), 925-941. https://doi.org/1 0.1080/09588221.2015.1068815.

Kuure, L. \& E. McCambridge 2007. Networks and place: a study of online activities in two focus groups. In O.-P. Salo \& T. Nikula (eds) Kieli oppimisessa - Language in Learning. AFinLA Yearbook 2007. Publications of the Finnish association of Applied Linguistics (AFinLA) 65, 137-156.

Källkvist, M. 2013. The engaging nature of translation: A nexus analysis of student-teacher interaction. In D. Tsagari \& G. Foloros (eds) Translation in language teaching and assessment. Cambridge: Cambridge Scholars Publishing, 115-134.

Larsen-Freeman, D. 2010. The dynamic co-adaptation of cognitive and social views: a chaos/ complexity theory perspective. In R. Batstone (ed.) Sociocognitive perspectives on language use and language learning. Oxford: Oxford University Press, 40-53. 
Larsen-Freeman, D. \& L. Cameron 2008. Complex systems and applied linguistics. Oxford: Oxford University Press.

Levine, G. S. 2012. The study of literary texts at the nexus of multiple histories in the intermediate college-level German classroom. L2 Journal, 4 (1), 171-188. https:// escholarship.org/uc/item/8kc726zc.

Levine, G. 2015. A nexus analysis of code choice during study abroad and implications for language pedagogy. In J. Cenoz \& D. Gorter (eds) Multilingual education between language learning and translanguaging. Cambridge: Cambridge University Press, 84-113.

Nishida, K. 1958. Intelligibility and the philosophy of nothingness. Tokyo: Maruzen.

Norris, S. 2004. Analyzing multimodal interaction: a methodological framework. London: Routledge.

Norris, S. 2016. Concepts in multimodal discourse analysis with examples from video conferencing. Yearbook of the Poznań Linguistic Meeting, 2 (1), 141-165. https://doi. org/10.1515/yplm-2016-0007.

Norris, S. \& R. H. Jones 2005. Preface. In S. Norris \& R. H. Jones (eds) Discourse in action. Introducing mediated discourse analysis. London: Routledge, xi-xii.

Palviainen, Å. \& K. Mård-Miettinen 2015. Creating a bilingual pre-school classroom: the multilayered discourses of a bilingual teacher. Language and Education 29 (5), 381-399. https://doi.org/10.1080/09500782.2015.1009092.

Pan, Y. 2014. Nexus analysis. In S. Norris \& C. D. Maier (eds), Interactions, images and texts. A reader in multimodality. Berlin: De Gruyter Mouton, 53-62.

Partanen, M. 2013. Suomen kielen oppimisen mahdollisuudet ja työyhteisön tuki puhdistuspalvelualalla: afrikkalaisten maahanmuuttajien käsityksiä ja kokemuksia. AFinLA Yearbook, 43(71), 55-76. https://journal.fi/afinlavk/article/view/60043.

Pietikäinen, S. 2012. Kieli-ideologiat arjessa. Neksusanalyysi monikielisen inarinsaamenpuhujan kielielämäkerrassa. Virittäjä, 116 (3), 410-442. https://journal.fi/ virittaja/article/view/7162.

Pietikäinen, S. 2015. Multilingual dynamics in Sámiland: rhizomatic discourses on changing language. International Journal of Bilingualism, 19 (2), 206-225. https://doi. org/10.1177/1367006913489199.

Pietikäinen, S., P. Lane, H. Salo \& S. Laihiala-Kankainen 2011. Frozen actions in the arctic linguistic landscape: a nexus analysis of language processes in visual space. International Journal of Multilingualism, 8 (4), 277-298. https://doi.org/10.1080/14790 718.2011.555553.

Pietikäinen, S. \& A. Pitkänen-Huhta 2013. Multimodal literacy practices in the indigenous Sámi classroom: children navigating in a complex multilingual setting. Journal of Language, Identity, and Education, 12 (4), 230-247. https://doi.org/10.1080/15348458 .2013.818471.

Prensky, M. 2001. Digital natives, digital immigrants. On the Horizon, 9 (5), 1-6. https://doi. org/10.1108/10748120110424816.

Riekki, M. 2016. Navigating change: nexus-analytic explorations in the field of foreign language education. Acta Universitatis Ouluensis, B Humaniora, 146. http://urn.fi/ urn:isbn:9789526214108.

Rish, R. M. 2015. Researching writing events: using mediated discourse analysis to explore how students write together. Literacy, 49 (1), 12-19. https://doi.org/10.1111/lit.12052.

Rish, R. M. \& J. Caton 2011. Building worlds together with collaborative writing: creative, social, and pedagogic challenges. English Journal, 100 (5), 21-28. http://www.jstor. org/stable/23047798. 
Rogers, R. \& I. Schaenen 2014. Critical discourse analysis in literacy education: a review of the literature. Reading Research Quarterly, 49 (1), 121-143. https://doi.org/10.1002/rrq.61.

Rosén, J. \& S. Bagga-Gupta 2015. Prata svenska, vi är i Sverige! [Talk Swedish, we are in Sweden!]: A study of practiced language policy in adult language learning. Linguistics and Education 31, 59-73. https://doi.org/10.1016/j.linged.2015.05.003.

Räisänen, S. 2015. Changing literacy practices: a becoming of a new teacher agency. Acta Universitatis Ouluensis. E Scientiae rerum socialium 154. http://urn.fi/ urn:isbn:9789526208480.

Schön, D. A. 1987. Educating the reflective practitioner: toward a new design for teaching and learning in the professions. San Francisco, CA: Jossey-Bass.

Scollon, R. 1998. Mediated discourse as social interaction: a study of news discourse. London: Longman.

Scollon, R. 2001a. Action and text: towards an integrated understanding of the place of text in social (inter)action, mediated discourse analysis and the problem of social action. In R. Wodak \& M. Meyer (eds) Methods in critical discourse analysis. London: Sage, 139-189.

Scollon, R. 2001b. Mediated discourse. The nexus of practice. London: Routledge.

Scollon, R. 2008. Discourse itineraries: nine processes of resemiotization. In V. K. Bhatia, J. Flowerdew \& R. H. Jones (eds) Advances in discourse studies. London: Routledge, 233-244.

Scollon, R. \& S. W. Scollon 2007. Nexus analysis: refocusing ethnography on action. Journal of Sociolinguistics 11 (5), 608-625. https://doi.org/10.1111/j.1467-9841.2007.00342.x.

Scollon, S. \& I. de Saint-Georges 2011. Mediated discourse analysis. In J. P. Gee \& M. Handford (eds) The Routledge handbook of discourse analysis. London: Routledge, 66-78.

Scollon, R. \& S. W. Scollon 2003. Discourses in place: language in the material world. London: Routledge.

Scollon, R. \& S. W. Scollon 2004. Nexus analysis: discourse and the emerging Internet. London: Routledge.

Strömmer, M. 2016a. Affordances and constraints: second language learning in cleaning work. Multilingua: Journal of Cross-Cultural and Interlanguage Communication, 35 (6), 697-721. https://doi.org/10.1515/multi-2014-0113.

Strömmer, M. 2016b. Material scaffolding: supporting the comprehension of migrant cleaners at work. European Journal of Applied Linguistics, 4 (2), 239-275. https://doi. org/10.1515/eujal-2015-0039.

Strömmer, M. 2017a. Mahdollisuuksien rajoissa. Neksusanalyysi suomen kielen oppimisesta siivoustyössä. Jyväskylä Studies in Humanities 336. http://urn.fi/ URN:ISBN:978-951-39-7265-3.

Strömmer, M. 2017b. Work-related language learning trajectories of migrant cleaners in Finland. Apples - Journal of Applied Language Studies, 11 (4), 137-160. https://doi. org/10.17011/apples/urn.201712214863.

Tapio, E. 2013. A nexus analysis of English in the everyday life of FinSL signers: a multimodal view on interaction. Doctoral thesis, University of Oulu. Jyväskylä: Jyväskylä University Printing Press.

Tapio, E. 2014. The marginalisation of finely tuned semiotic practices and misunderstandings in relation to (signed) languages and deafness. Multimodal Communication, 3 (2), 131-142. https://doi.org/10.1515/mc-2014-0010

Van Leeuwen, T. 2005. Introducing Social Semiotics. London: Routledge.

Van Lier, L. 2000. From input to affordance: social-interactive learning from an ecological perspective. In J. Lantolf (ed.) Sociocultural theory and second language learning. Oxford: Oxford University Press, 245-259. 
Van Lier, L. 2004. The semiotics and ecology of language learning. Perception, voice, identity and democracy. Utbildning \& Demokrati, 13 (3), 79-103.

Virtanen, A. 2017. The multivoicedness of workplace literacies: an international nursing student documenting in a second language. European Journal of Applied Linguistics 5 (1), 115-140. https://doi.org/10.1515/eujal-2015-0015.

Vygotsky, L. S. 1978. Mind in society: the development of higher psychological processes. Cambridge, MA: Harvard University Press.

Vygotsky, L. S. 1981. The instrumental method in psychology. In J. V. Wertsch (ed.) The concept of activity in Soviet psychology. New York: M.E. Sharpe, 134-143.

Wertsch, J. V. 1991. Voices of the mind: a sociocultural approach to mediated action. Cambridge, MA: Harvard University Press.

Wohlwend, K. 2009. Mediated discourse analysis: researching young children's non-verbal interactions as social practice. Journal of Early Childhood Research, 7 (3), 228-243. https://doi.org/10.1177/1476718X09336950.

Wohlwend, K. \& L. J. Handsfield 2012. Twinkle, twitter little stars: tensions and flows in interpreting social constructions of the techno-toddler. Digital Culture \& Education, 4 (2), 185-202. http://www.digitalcultureandeducation.com/cms/wp-content/ uploads/2012/09/dce_1058_wohlwend.pdf. 